\title{
Making of the Colonial Visualization of Indian Floras and Faunas
}

\author{
Book Review
}

\author{
Memories of Belonging: Images from the Colony and Beyond, by Malavika Karlekar, Niyogi Books, New \\ Delhi, 2014, 228 pages, US\$25, ISBN: 9789383098590.
}

In book "Memories of Belonging: Images from the Colony and Beyond" distinguished academician and newspaper columnist MalavikaKarlekar presents a collection of colonial images and imaginations with their historical anecdotes. She brings back the memories of colonial India using a set of archival images - photographs, lithographs, drawings and picture postcards. This book contains the reproduction of several hand-coloured illustrations of floras and faunas commonly available during the colonial period (eighteenth to twentieth centuries), with narratives of time, space, and subjects. This book is systematically structured with four sections on a diverse range of topics, namely, (i) Introduction, (ii) Of Birds, Bungalows and Preoccupations, (iii) Points on a Compass, and (iv) Wanderings of a Pilgrim and Others. Each section contains several small chapters to imbibe light read to the quick readers. Most of these chapters printed here earlier appeared as a column in The Telegraph, a newspaper published from Kolkata.

The fascinating journeys of the colonial masters are described here with the intriguing style to capture series of happenings in their lives. For example, in the chapter titled "A Missionary's Passion" Karlekar highlights life and works of William Carey, a man of many facets. He was the founder of the Baptist Missionary Society, a co-founder of the Agricultural and Horticultural Society of India, the Bible translator who translated it into Bengali and Sanskrit, and the founder of Serampore College - a premier institution for imparting western education in Colonial India. Carey was a naturalist and specialist in Indian floras. He brought in many plants from England and grew them in Serampore in his five-acre garden alongside the Hooghly or Ganges River. His private collection of botanical specimens was second only to that of the East India Company's Calcutta Botanic Gardens. He became a close friend of William Roxburgh, the head of the Calcutta Botanic Gardens. Roxburgh published a catalogue of the plants growing in the Botanic Gardens, for which Carey was also consulted and wrote an introduction. In other few chapters, Karlekar highlights life and works of specialists of Indian faunas and birds. The author reproduces several hand-coloured illustrations of Indian floras and faunas in those chapters.

William and Thomas Daniell were among the most famous illustrators during the late eighteenth and early nineteenth centuries. Their illustrations and lithographs had captured long-lasting imaginaries of Colonial past before the photography became a standard method to capture images. The author observes in this book: "In the early years, detailed drawings and lithographs were used extensively, and often, individual artists with nothing more than pecuniary interests in mind became pioneers of a style that lent itself easily to professional use and analysis. A few artist-travellers ... produced impressive folios, many of their visual depictions providing insights into the country's geographic and ecological diversity, and architectural sites as well as into Indian society, occupations and customs" (p. 63). In this book, Karlekar reproduces many of the famous illustrations and lithographs created by William Daniell and his contemporary artists.

This book also presents several rare black \& white photographic and lithographic images, captured by well-known as well as lesser-known amateur photographers. The black and white images of Indian monuments reproduced in this book such as Taj Mahal, QutubMinar, Agra Fort, Gateway of India, and Kalighat Temple, were captured more than a hundred years ago. These images testify the interests of European travellers in exploring the heritage sites in India and conserving their surroundings by the colonial rulers. However, many of the priceless artefacts, found in the heritage sites, were shifted and transferred to private and public collections in England and the other parts of Europe during the British Raj. 
The author discusses the life of various colourful British personalities who were born and lived in India during the colonial period, e.g., Rudyard Kipling and Edward James (Jim) Corbett. Kipling later became a Noble laureate in literature, while Jim Corbett became a famous adventurercum-hunter. The book also explores how British were passionate in developing hill stations across the Himalayan regions in the country. They developed hill stations such as Simla, Mussourie, and Darjeeling to avoid a scorching summer in their erstwhile state capitals.

The book turns out an interesting book on colonial images and imaginations as recorded during the British Raj by the British commoners. Narratives of Karlekar appear appropriate for the readers keen to know the socio-cultural fabrics of the British commoners. The book also showcases how the communicators in British India often used befitting imageries for communicating biodiversity and sociocultural milieu.

\section{Anasua Mukherjee Das}

Coordinator, BRICLICS

Purvanchal Complex, JNU Campus, New Delhi 110067, India; Email: AnasuaMukherjeeDas@gmail.com DOI: 10.5530/jscires.5.2.11

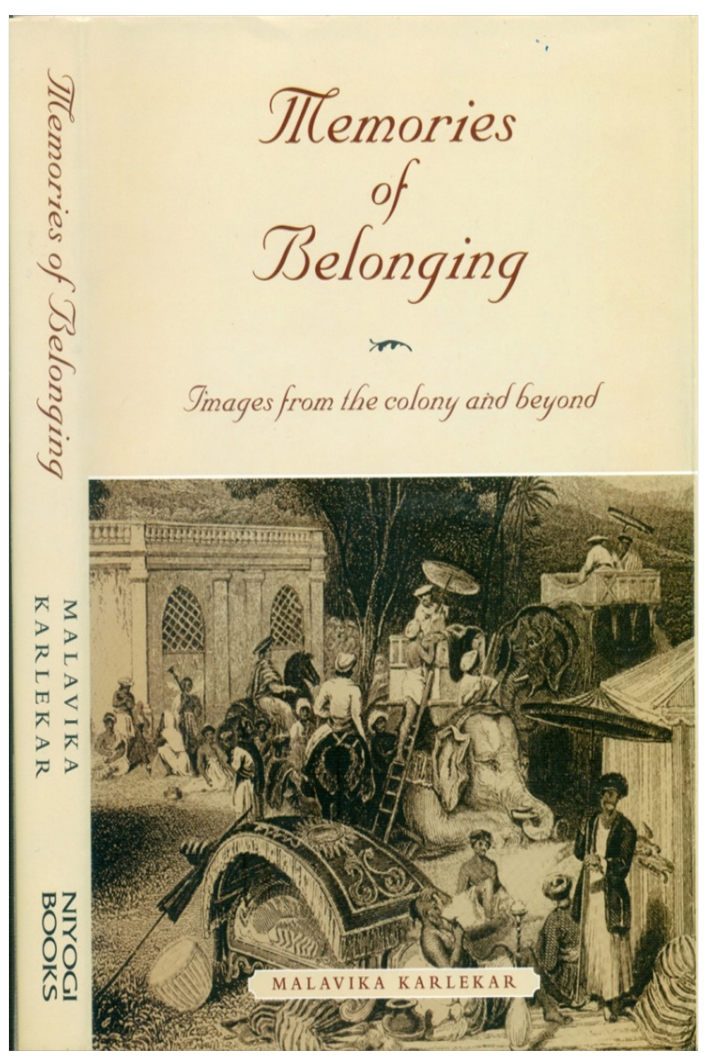

